\title{
Problematika Dakwah di Kanagarianan harau Kecamatan Harau Kabupaten Lima Puluh Kota
}

\author{
Al Ikhlas \\ alikblas@,fis.unp.ac.id \\ Murniyetti \\ murniyetti@,fis.unp.ac.id \\ Ahmad Rivauzi
abmadrivauzi@fis.unp.ac.id \\ Wirdati \\ wirdati@fiss.unp.ac.id
}

\begin{abstract}
Abstrak
Islam merupakan agama dakwah yaitu agama yang mengandung nilai-nilai lubur sebagai pedoman dalam kehidupan untuk disampaikan kepada seluruh umat manusia. Tidak hanya terbatas pada kelompok tertentu, golongan tertentu, suku tertentu ataupun bangsa tertentu. Akan tetapi untuk kaffatan linnasi (selurub umat manusia) kapanpun dan dimanapun. Dakwah Islam berisikan ajakan kepada yang ma'ruf (kebaikan) dan menjaubi segala hal yang munkar (keburukan). Sebab dengan melaksakan kebaikan dalam kehidupan dan menjaubi segala keburukan maka terciptalah kehidupan yang harmoni dan penuh dengan kebahagiaan. Dalam setiap aktivitas dakwah, ada enam hal yang harus diperbatikan dengan baik, agar dakwah yang dilakukan tersebut berbasil dan mendatangkan kebaikan. Enam hal tersebut adalah: dai, mad'u, pesan dakwah, media dakwah, feedback dakwah dan metode dakwah. Sedangkan tujuan dari sebuah dakwah adalah untuk. memperbaiki kehidupan manusia agar bahagia dunia dan akbirat. Kenagarian Harau, Kecamatan Harau, Kabupaten Lima Puluh Kota yang merupakan wilayah tempat kami melakukan kegiatan pengabdian. Di sana ditemukan beberapa permasalahan yang dibadapi oleh masyarakat terkait dengan aktifitas dakwah. Diantaranya, Pertama, kurangnya jumlah personel da $i$ sehingga tidak. terpenubinya kebutuhan masyarakat untuk kegiatan da'wiyah. Kedua, kurangnya kompetensi sebagian para da $i$ sehingga hal-hal atau tradisi lama yang tidak sesuai dengan syara menjadi kebiasaan masyarakat. Ketiga, kurangnya keterampilan da'I dalam beberapa aktivitas keagamaan terutama pada pelaksanaan ibadah shalat Jum at dan penyelenggaraan jenazah.
\end{abstract}

Kata Kunci: Problematika, Dakwah, Harau, Lima Puluh Kota

\section{A. Pendahuluan}

Islam merupakan agama yang disempurnakan oleh Nabi Muhammad SAW sebagai nabi dan rasul terakhir bagi umat manusia. Setelah disempurnakan maka tidak ada lagi penambahan atau pengurangan dalam syariat Islam. kesempurnaan Islam sebagai panduan dalam kehidupan dijelaskan Allah SWT dalam firman-Nya:

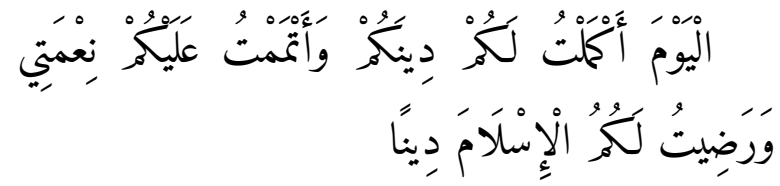


Artinya: Pada hari ini telah Kusempurnakan untuk

kamu agamamu, dan telab Ku-cukupkan kepadamu nikmat-Ku, dan telab Ku-ridhai Islam itu jadi agama bagimu. (QS. Al-Maidah: 3)

Dalam kesempurnaan ajaran Islam, terkandung amanat untuk menyampaikan risalah dan dakwah yaitu berupa basyiran "berita gembira" dan nadziran "peringatan" kepada seluruh umat manusia tanpa terkecuali. Jadi, Islam tidak hanya untuk kelompok tertentu saja bangsa tertentu saja, akan tetapi kepada seluruh umat manusia dimanapun mereka berada. Hal ini dijelaskan dalam firman Allah SWT:

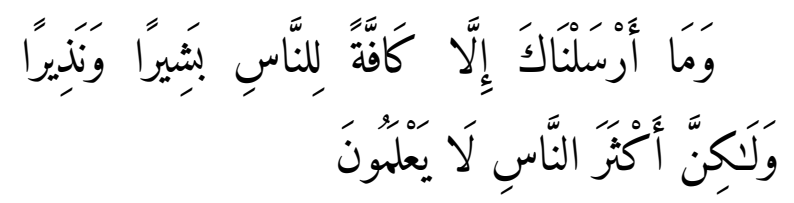

Artinya: Dan Kami tidak mengutus kamu, melainkan kepada umat manusia selurubnya sebagai pembawa berita gembira dan sebagai pemberi peringatan, tetapi kebanyakan manusia tiada mengetahui. (QS. Saba: 28)

Di antara berita gembira yang dibawa oleh Islam menggambarkan nilai-nilai kejadian manusia dan ketinggian martabatnya diantara seluruh makhluk yang diciptakan Allah SW'T ${ }^{1}$. Diciptakannya manusia dari material yang sempurna yaitu tanah dan bentuk yang sempurna. Sehingga ia menjadi rahmat yang sangat besar dari Allah SWT untuk alam semesta. Hal ini dijelaskan oleh Allah SWT dalam firmannya:

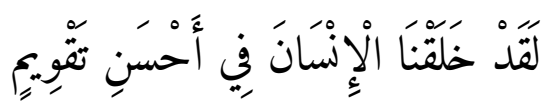

Artinya: Sesunggubnya Kami telah menciptakan manusia dalam bentuk yang sebaik-baiknya. (QS. At-Tin: 4)

Hikmah dibalik penciptaan manusia dalam keadaan sempurna adalah karena mereka

${ }^{1}$ Mohammad Nasir, Fiqhud Da'wah, (Jakarta: Media Dakwah, 2000), h. 3 dipersiapkan untuk menjadi khalifah di permukaan bumi. ${ }^{2}$ Hal inilah yang menjadikan manusia istimewa dari makhluk Allah SWT yang lainnya. Mesekipun Allah SWT ciptakan malaikat dari cahaya dan Iblis dari Api. Namun, penciptaan manusia merupakan hal yang istimewa. Hal ini dijelaskan Allah SWT dalam firman-Nya:

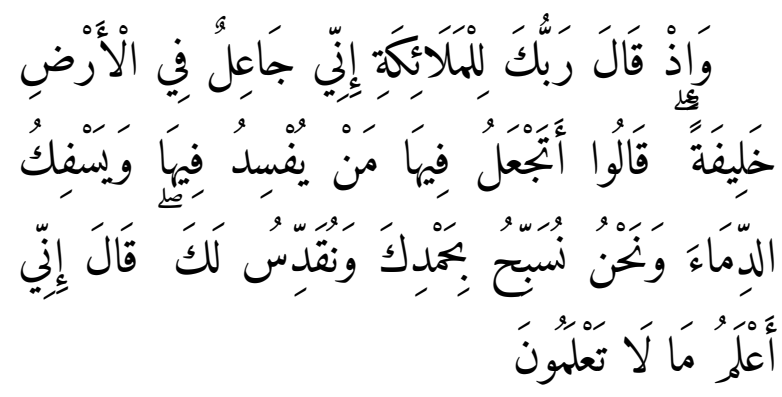

Artinya: Ingatlah ketika Tuhanmu berfirman kepada para Malaikat: "Sesunggubnya Aku bendak menjadikan seorang khalifah di muka bumi". Mereka berkata: "Mengapa Engkau bendak menjadikan (khalifah) di bumi itu orang yang akan membuat kerusakan padanya dan menumpabkan darah, padabal kami senantiasa bertasbih dengan memuji Engkau dan mensucikan Engkau?" Tuhan berfirman: "Sesunggubnya Aku mengetabui apa yang tidak kamu ketabui". (QS. Al-Baqarah: 30)

Pengertian khalifah atau pengganti, berfungsi menugaskan dan membebankan (taklif) kepada manusia untuk melaksanakan tugas-tugas kehidupan di dunia ini. Dalam hal ini manusia diberi potensi berupa kekuatan fisik dan kekuatan untuk berfikir. Meskipun manusia dianuegerahi akal, namun akal manusia sangatlah terbatas. Oleh sebab itu, kemampuan berfikir yang dimiliki manusia bukanlah satusatunya cara untuk dapat memecahkan segala permasalahan dalam mengemban amanah sebagai khalifah.

${ }^{2}$ M. Dawam Raharjo, Islam dan Transformasi Budaya, (Yogyakarta: Dana Bhakti Prima Yasa, 2002), h. 79 
Manusia juga diberi rasa dan nafsu yang saling mempengaruhi dalam setiap gerak langkah manusia. Kecenderungan nafsu akan selalu mengarah kepada kejahatan dan kerusakan apabila pikiran dan rasa manusia sudah tidak mampu untuk mengendalikannya. Oleh sebab itu, terkadang manusia cenderung melakukan keburukan dalam kehidupannya. Allah Swt menjelaskan dalam firman-Nya:

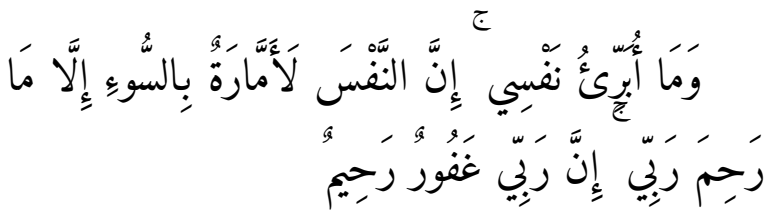

Artinya: Dan aku tidak membebaskan diriku (dari

kesalaban), karena sesunggubnya nafsu itu selalu menyuruh kepada kejahatan, kecuali nafsu yang diberi rahmat oleb Tubanku. Sesungsubnya Tubanku Maba Pengampun lagi Maba Penyanyang. (QS. Yusuf: 53)

Sebagai seorang khalifah, manusia harus menyampaikan atau mendakwahkan ajaran Islam kepada siapaun karena Islam merupakan agama misionary, yaitu agama yang harus disampaikan kepada orang lain. Dengan tujuan setiap orang mampu mengenal dan masuk kedalam ajaran Islam. $^{3}$ Mengenal segala kebaikan yang ditawarkan Islam demi terwujudknya keselamatan hidup dunia dan akhirat.

Oleh karena itu, dalam kehidupan sosial, umat Islam dituntut dan bertanggungjawab untuk mengajak mengerjakan perbuatan yang baik (ma'ruf) sekaligus meninggalkan perbuatan yang tidak baik atau yang tercela (mungkar). Ini berarti manusia tidak bisa terlepas dari fungsi untuk melaksanakan dakwah. Allah Swt jelaskan dalam friman-Nya:

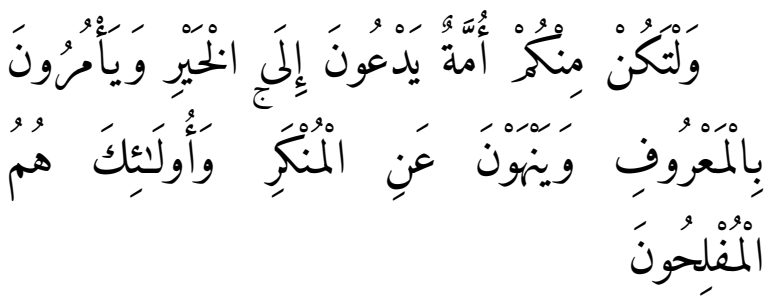

Artinya: Dan hendaklah ada di antara kamu segolongan umat yang menyeru kepada kebajikan, menyurub kepada yang ma'ruf dan mencegah dari yang munkar; merekalah orang-orang yang beruntung. (Qs. Ali Imran: 104)

Salah satu tujuan dari dakwah Islam adalah untuk menjamin akan terwujudnya kebahagiaan dan kesejahteraan. Sebab ajaran Islam merupakan pedoman hidup umat Islam yang harus dilaksanakan secara konsisten serta konsekuen. $^{4}$

Dalam tulisan ini, penulis akan menguraikan beberapa problematikan yang dihadapi oleh masyarakat di Kanagarianan Harau, Kecamatan Harau, Kabupaten Lima Puluh Kota. Sebagaimana yang diketahui, mayortas masyarakat Kanagarianan Harau adalah muslim dan kebanyakan mereke berprofesi sebagai petani.

Kondisi georgrafis yang dipenuhi perbukitan, serta ladang-ladang masyarakat yang berjauhan. Hal ini menjadi permasalahan bagi masyarakat Kanagarianan Harau dalam melakukan beberapa ritual keagamaan. Ditambah lagi dengan kurangnnya jumlah dai atau mubaligh yang mampu memimpin dalam kegaitan-kegiatan keagamaan seperti shalat Jum `at dan juga penyelenggaraan jenazah menjadi pemasalahan bagi masyarakat disana. Semoga bermanfaat.

\section{B. Pembahasan}

\section{Konsep Dakwah Dalam Islam}

3 Sahal Mahfud, Nuansa Fiqih Sosial, (Yogyakarta: LKiS, 1994), h. 111

4 Siti Muriah, Metodologi Dakwah Kontemporer, (Yogyakarta: Mitra Pustaka, 2000), h. 12 


\section{a. Pengertian Dakwah}

Kata dakwah berasal dari bahasa Arab, yakni (دعوة). Makna dari kata ini beragam, namun makna yang populer adalah mengajak, menyeru, memanggil, meminta, dan mengundang. Dari beberapa arti tersebut, dapat diketahui bahwa dakwah merupakan kegiatan persuasif yakni mengajak manusia kepada yang ma 'ruf (kebaikan) dan mencegah pada yang munkar (keburukan). Dengan demikian dalam sebuah aktivitas atau kegiatan dakwah, proses lebih diutamakan dari pada sebuah hasil dari dakwah itu sendiri. ${ }^{5}$

Adapun secara istilah, Syaikh Ali Mahfuzh mengatakan bahwa dakwah adalah perkara memotivasi manusia untuk berbuat kebaikan, mengikuti petunjuk, memerintahkan kebaikan dan mencegah kemunkaran agar mereka memperoleh kebahagiaan hidup di dunia dan akhirat nantinya. ${ }^{6}$

Sedangkan menurut Prof. A. Hasjmy bahwa dakwah adalah mengajak orang lain untuk meyakini dan mengamalkan aqidah dan syariat Islam yang terlebih dahulu telah diyakini dan diamalkan oleh pendakwah itu sendiri. ${ }^{7}$ Artinya sebelum seorang meyampaikan dakwah, ia terlebih dahulu telah mengamalkannya dalam kehidupan sehari-hari.

Adapun Prof. Toha Yahya Omar, dakwah adalah mengajak manusia dengan cara bijaksana kepada jalan yang benar sesuai dengan perintah tuhan, untuk keselamatan dan kebahagiaan mereka di dunia dan akhirat. ${ }^{8}$ Dapat dipahami bahwa dakwah harus disampaikan dengan cara yang baik dan jauh

5 Moh. Ali Aziz, Imu Dakwah. (Jakarta: Pranadamedia Group, 2004) h. 10

${ }^{6}$ Ali Mahfudz, HidayatAl-Mursyidin, (Cairo; Dar AlKutub Al-Arabiyah, 1952), h. 1 dari kekerasan. Sebab jika disampaikan dengan kekerasan, maka orang akan menolaknya.

Dari beberapa definisi yang telah diurakan di atas dapat kita simpulkan bahwa dakwah adalah:

1. Dakwah merupakan sebuah aktifitas untuk menyeru orang lain kepada yang baik dan mencegah mereka dari hal-hal yang buruk (amar ma'ruf wa nabi munkar).

2. Hal yang baik dan buruk tidak ditentukan oleh akal manusia akan tetapi ditentukan oleh syariat Islam yaitu merujuk kepada al-Qur'an dan Sunnah.

3. Menyeru manusia kepada kebaikan ataupun mencegah mereka dari keburukan harus dilakukan dengan penuh hikmah dan kebijaksanaan. Tidak boleh dengan cara yang anarkis atupun penuh kekerasan. Sebab cara yang demikian hanya akan menimbulkan kebencian dan permusuhan bukan cinta dan kasih sayang.

4. Aktivitas dakwah tujuannya adalah untuk mengajak manusia untuk sampai pada kemashlahatan hidup di dunia dan akhirat. Kemahslahatan tersebut berupa kebahagiaan hidup di dunia dan akhirat nantinya.

Dakwah merupakan tugas yang sangat mulia. Oleh sebab itu tugas ini diembankan kepada nabi dan rasul yang mulia. Mengajak ataupun menunjuki seseorang kepada kebaikan maka sungguh ia mendapatkan pahala yang sama dengan pelakunya. Rasulullah SAW bersabda:

7 Samsul Munir Amin, Imu Dakwah, (Jakarta: Amzah, 2009), h. 3

8 Toha Yahya Omar, Islam dan Dakwah, Jakarta: Zakia Islami Press, 2004), h. 67 


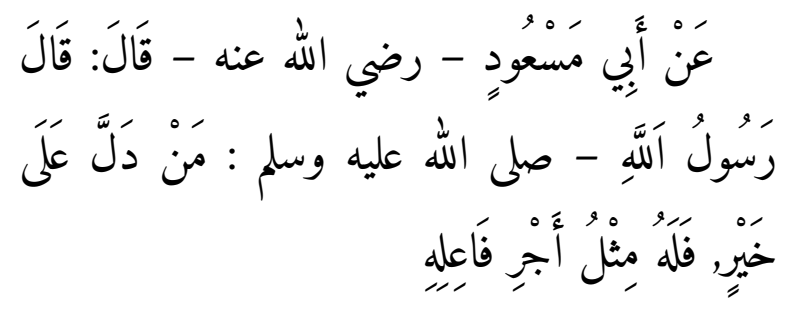

Artinya: Dari Abu Mas'ud RA berkata, "Rasúlullâh Shallallabu 'alaibi wa sallam bersabda, Barangsiapa menunjukekan suatu kebaikan, maka ia mendapatkan pabala seperti pabala orang yang melakukannya.” (HR. Muslim)

\section{b. Unsur-unsur Dakwah}

Dalam sebuah aktivitas dakwah, ada enam unsur yang harus diperhatikan. Sebab keenam unsur tersebut sangat menentukan berhasil atau tidaknya sebuah aktivitas dakwah. Enam unsur tersebut adalah:

\section{Pertama: Da`i (Pendakwah)}

Da $i$ adalah orang memainkan peran utama dalam sebuah dakwah. Ia memiliki peran yang sangat menentukan sebuah dakwah. Dalam ilmu komunikasi, da'i atau pendakwah adalah komunikator, yakni orang yang menyampaikan pesan dakwah kepada orang lain. Dalam buku Ilmu Dakwah kualifikasi da’i ada dua macam, yakni secara umum dan khusus.

Secara umum, dakwah diharuskan untuk semua muslim yang mukallaf sebagai bentuk kepatuhan atas perintah Nabi SAW, untuk menyampaikan dakwah kepada umat manusia. Secara khusus, penyebaran dakwah Islam diharuskan pada muslim yang mumpuni dalam bidang agama seperti ulama, guru, kiai, dan lain sebagainya.

Oleh sebab itu, dakwah menjadi tugas setiap kita setiap muslim. Sebab berdakwah tidak mesti di podium, di mimbar, di mesjid dan

\footnotetext{
9 Wahyu Ilaihi, Komunikasi Dakwah, (Bandung: PT Remaja Rosdakarya, 2013) h. 16-175
}

lain sebagianya. Kapanpun dan dimanapun, aktivitas berupak kebaikan yang kita lakukan bisa bermakna sebuah dakwah.

\section{Kedua: Mad`u (Orang yang Menerima Dakwah)}

Abu Fath al-Bayanuni berpendapat bahwa mad'u adalah siapa pun yang menjadi penerima pesan dakwah. Sebutan lain dari mad'u adalah mitra dakwah, bukan dikatakan sebagai objek dakwah atau sasaran dakwah dengan maksud agar pendakwah menjadi kawan berpikir dan bertindak bersama dengan mitra dakwah.

Dan bisa jadi, pendakwah itu sendiri menjadi mitra dakwah bagi pendakwah lainya. Sebab dalam Islam, di antara kewajiban satu mukmin dengan mukmin lainnya adalah saling meberikan nasehat dalam kebenaran dan nasehat dalam kesabaran. Allah SWT berfirman:

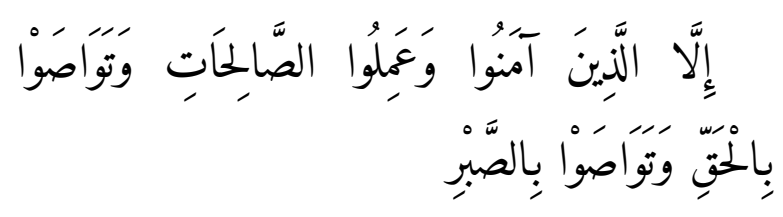

Arrinya: kecuali orang-orang yang beriman dan mengerjakan amal saleh dan nasehat menasehati supaya mentaati kebenaran dan nasehat menasehati supaya menetapi kesabaran. (QS. AlAshr: 03)

\section{Ketiga: Pesan Dakwah}

Setiap dakwah pasti memiliki pesan dan pesan yang disampaikan itu adalah nilai-nilai ajaran Islam. Agar nilai-nilai kebenaran yang disampaikan oleh pendakwah dapat diterima oleh mitra dakwah, maka ia harus disampaikan dengan cara yang baik dan dikuatkan dengan argumentasi logis. Sehingga tidak ada alasan 
bagi mitra dakwah untuk menolak akan nilainilai kebenaran yang disampaikan.

Maka, yang menjadi sumber dari pesanpesan dakwah adalah al-Qur'an dan Sunnah. Sebab keduanya merupakan sumber utama dari nilai-nilai ajaran Islam. Dari kesemua materi yang terkandung dalam al-Qur'an dan Sunnah, dapat dikelompokkan menjadi tiga, yaitu:

\section{1) Pesan Akidah}

Pesan akidah berarti nilai-nilai agama Islam yang berkaitan dengan keimanan. Hal ini merupakan prinsip utama dalam agama Islam dan ia menjadi pondasi dalam beragama. Hal ini tertuang dalam rukun Iman, yaitu: Iman kepada Allah SWT, iman kepada Malaikat, iman kepada Kitab, iman kepada Rasul, iman kepada Hari Akhir dan iman kepada Kadar Baik dan Kadar Buruk.

\section{2) Pesan Syari ah}

Pesan syari'ah berarti nilai-nilai yang berkaitan dengan hukum yang ditetapkan oleh Allah SWT dalam kehidupan manusia. Hukum yang mengatur hubungan manusia dengan Allah SWT atau disebut juga dengan Hablum Minallah. Sehingga yang dinamakan dengan Ibadah Mahdhah. Sedangkan hukum yang mengatur hubungan manusia dengan manusia yang dinamakan dengan Hablum Minannasi dinamakan dengan Ibadah Ghairu Mahdhah.

Bentuk dari ibadah mahdhah adalah seperti shalat, puasa, haji dan beberapa ibadah lainnya. Sedangkan ibadah ghairu mahdhah seperti berjual beli, penikahan, dan beberapa bentuk ibadah lainnya.

\section{3) Pesan Akhlak}

Akhlak Pesan akhlak berarti nilai-nilai Islam yang berhubungan dengan tingkah laku manusia baik sebagai seorang hamba maupun akhlak kepada sesama dan semesta alam.
Tingkah laku manusia sebagai seorang hamba dapat dilihat bagaimana interaksi sosialnya dengan sesama manusia. Hal ini memiliki dua aspek nilai, yaitu baik atau buruk.

Pada aspek baik seperti senantiasa menolong orang yang membutuhkan bantuan, berbakti kepada kedua orang tua atau bahkan hanya menyingkirkan duri dari jalanan. Sedangkan aspek buruknya adalah suka bergujing, mengadu domba, menimbulkan fitnaha atau sifat-sifat lain yang dapat merusak hubungan sosial di tengah masyarakat.

\section{Keempat: Media Dakwah}

Dalam buku Ilmu Dakwah karya Moh. Ali Aziz, dikatakan bahwa media dakwah merupakan unsur tambahan di dalam dakwah. Maksudnya kegiatan dakwah boleh dan dapat berlangsung meski tanpa media. Kata media berasal dari bahasa Latin medius yang secara harfiah berarti perantara, tengah atau pengantar. Sedangkan dalam bahasa Arab media sama dengan wasilah atau dalam bentuk jamaknya yakni wasail yang berarti alat atau perantara.

Jadi fungsi dari media dakwah adalah sebagai perantara yang memudahkan bagi seorang pendakwah dalam mentranfer pesan dakwahnya kepada mitra dakwahnya. Hasil yang didapatkan lebih baik, usaha yang dilakukan lebih efisien dan cara penyampaian dakwahpun menjadi lebih efektif.

Terlebih di zaman sekarang, sebagai dampak dari revolusi industri 4.0 kemajuan teknologi di bidang informasi luar biasa. Hal ini juga berpengaruh kepada pengembangan media dalam berdakwah. Bagaimana seorang da'I atau pendakwah bisa memanfaatkan kemajuan teknologi tersebut untuk menyampaikan pesan dakwahnya dengan baik tanpa harus mendatangi mereka nyata. Akan tetapi dakwah bisa dilakukan secara virtual ataupun daring. 


\section{Kelima: Efek Dakwah atau Feedback}

Sebuah dakwah yang berhasil harus memberikan efek kepada mad' $u$ atau mitra dakwah. Hal ini ditandai dengan adanya respon dari mitra dakwa tersebut sebagai penerima pesan-pesan dakwah. Hal ini menandakan mereka memahami pesan dakwa yang disampaikan sehingga menghasilkan feedback atau umpan balik dari setiap pesan yang disampaikan.

Namun, jika mitra dakwah tidak memberikan umpan balik dari pesan dakwah yang telah disampaikan, bisa jadi mereka tidak memahami pesan dakwah yang telah disampaikan. Sehingga hal ini menandakan dakwah yang dilakukan tidak berhasil atau kurang berhasil.

\section{Keenam: Metode Dakwah}

Dari segi bahasa metode berasal dari dua kata yakni meta yang berarti "melalui" dan hodos yang berarti "jalan, cara". Menurut Toto Tasmara, metode dakwah merupakan cara-cara tertentu yang dilakukan oleh seorang da'i dalam mengajak mitra dakwah untuk mencapai suatu tujuan atas dasar hikmah dan kasih sayang.

Terdapat tiga cara dakwah yang disampaikan Allah SWT dalam al-Qur'an yaitu pada surat al-Nahal, yaitu:

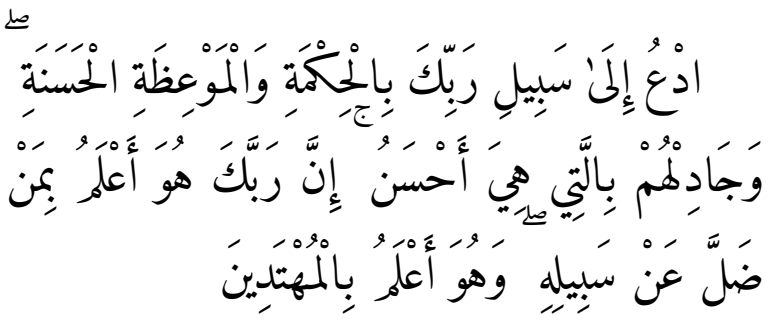

Artinya: Serulah (manusia) kepada jalan Tuban-mu dengan bikmah dan pelajaran yang baik dan bantablah mereka dengan cara yang baik.

${ }^{10}$ M. Munir, Metode Dakwah, (Jakarta: Prenadamedia Group, 2003) h. 6-18
Sesunggubnya Tubanmu Dialah yang lebih mengetabui tentang siapa yang tersesat dari jalanNya dan Dialah yang lebih mengetahui orangorang yang mendapat petunjuk (QS. Al-Nahal: 125)

Dari ayat di atas dapat kita simpulkan bahwa metode dakwah yang diajarkan Islam sebagai berikut:

Pertama, al-hikmah. Menurut Imam Abdullah bin Ahmad Mahmud An-Nasafi bahwa cara al-hikmah adalah dakwah yang disampaikan dengan menggunakan perkataan yang benar dan pasti, yaitu adil dalam menjelaskan kebenaran dan menghilangkan rasa keraguan.

Kedua, al-Mau izhah. Cara al-manizhah yaitu dengan memberikan pelajaran-pelajaran yang baik kepada mitra dakwah. Menjelaskan tentang pelajaran-pejaran yang besumber dari al-Qur'an dan Sunnah yang menjelaskan kisah-kisah umat terdahulu serta pelajaran yang berharga yang dapat dipetik dari kisah-kisah tersebut.

Ketiga, al-Hasanah. Dengan cara debat yang baik yang tujuannya adalah untuk menemukan kebenaran tanpa ada sedikit pun rasa untuk menjatuhkan lawan debat. ${ }^{10}$ Sebagain orang berdebat bukan untuk mencari kebenaran, akan tetapi untuk menunjukkan kepiawainnya dalam menyusun argumen atau untuk mempemalukan lawan debatnya. Hal ini merupakan hal yang terlarang dan jauh dari akhlak seorang pendakwah muslim.

\section{c. Tujuan Dakwah}

Dalam pandangan M. Syafaat Habib, tujuan utama dakwah adalah akhlak yang mulia (akblâq al-karimah). Tujuan ini, menurutnya, paralel dengan misi diutusnya Nabi Muhammad SAW. 
yaitu untuk menyempurnakan akhlak manusia. Berdasarkan hadis:

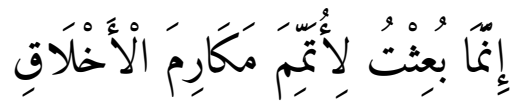

Artinya: Sesungghnya aku diutus untuk menyempurnakan akblak mulia. ${ }^{11}$

Sedangakan menurut Jamaluddin Kafie menjelaskan bahwa dakwah memiliki beberapa tujuan yaitu: Pertama. Tujuan hakiki yaitu mengajak manusia untuk mengenal Tuhannya dan mempercayai-Nya sekaligus mengikuti jalan petunjuk-Nya. Kedua. Tujuan umum, yaitu menyeru manusia untuk mengindahkan dan memenuhi seruan Allah dan Rasul-Nya. Ketiga. Tujuan khusus, yaitu bagaimana membentuk suatu tatanan masyarakat Islam yang utuh (kâffah). ${ }^{12}$

Sedangkan menurut M. Bahri Ghazali, dengan berdasarkan pada aspek kelangsungan suatu kegiatan dakwah, ia membagi tujuan dakwah kepada tujuan jangka pendek dan tujuan jangka panjang. Yang pertama dimaksudkan untuk memberikan pemahaman tentang Islam kepada masyarakat sasaran dakwah. Yang kedua, mengadakan perubahan sikap masyarakat itu sendiri. Dengan tujuan pertama diharapkan pemahaman masyarakat tentang Islam, sehingga masyarakat akan terhindar dari perbuatan munkar. Sedangkan dengan tujuan kedua, diharapkan terwujudnya perubahan sikap dan perbuatan masyarakat dari kecenderungan berperilaku tidak terpuji menjadi masyarakat yang terbebas dari segala bentuk kemaksiatan. Kedua tujuan ini, menurutnya, tergambar firman Allah Swt:

11 M. Syafaat Habib, Buku Pedoman Dakwah, (Jakarta: Widjaya, 1982), h. 129

12 Jamaluddin Kafie, Psikologi Dakwah: Bidang Studi dan Bahan Acuan, (Surabaya: Offset Indah, 1993), 66

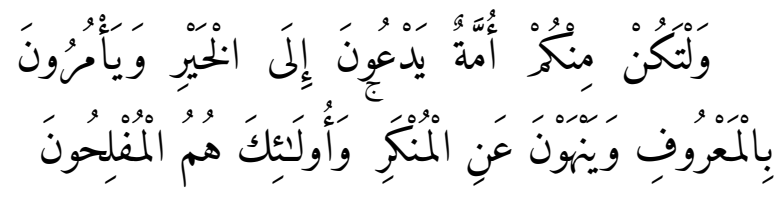

Artinya: Dan hendaklah ada di antara kamu segolongan umat yang menyeru kepada kebajikan, menyurub kepada yang ma'ruf dan mencegah dari yang munkar; merekalah orang-orang yang beruntung. (QS. Ali Imran: 104)

Ayat ini dinilainya, selain mengandung tujuan dakwah jangka pendek dan jangka panjang, juga menekankan sasaran dari tujuan itu yakni tercapainya masyarakat sejahtera, bahagia di dunia dan di akhirat. ${ }^{13}$

\section{Problematika}

Dakwah

di

\section{Kanagarianan Harau}

Kanagarian Harau berada di Kecamatan Harau, Kabupaten Limapuluh Kota, Provinsi Sumatra Barat. Luas Kanagarian Harau: 78,83 kilometer persegi atau 18,91 persen dari luas wilayah Kecamatan Harau. Berjarak sekitar 8 kilometer dari ibu kota kecamatan, 6 kilometer dari ibu kota kabupaten Sarilamak.

Nagari yang berdampingan dengan salah satu destinasi wiasata yang terkenal di Sumatera Barat ini berpenduduk 3.063 jiwa (2018), yang terdiri dari 1.549 laki-laki dan 1.514 perempuan. ${ }^{14}$ Kanagarian Harau terdiri dari 7 jorong, yakni: 1) Harau, 2) Padang Tarok, 3) Hulu Aia Koto Marapak, 4) Hulu Aia Koto, 5) Hulu Aia Batu Badukuang, 6) Landai dan 7) Sungai Data. Sedangkan fasilitas yang terdapat di Kanagarian tersebut adalah SD 3 unit, SMP 5 unit dan SMA 2 unit.

Mayoritas pendapatan masyarakat Kanagarian Harau adalah dari bertani gambir.

${ }^{13}$ Ghazali, Dakwah Komunikatif: Membangun Kerangkea Dasar Ilmu Komunikasi Dakwah (Jakarta: Pedoman Ilmu, 1997), h. 7

14 Data ini diperoleh pada akhir tahun 2019 dari Badan Pusat Statistik Kabupaten Lima Puluh Kota. 
Disamping ada pekerjaan lain yang ditekuni seperti bertanam padi atau tanaman-tanaman pertanian lainnya. Begitu juga dengan strata pendidikan yang menjelaskan bahwa kebayanyakan dari masyarakat Harau tidak mengecap penididikan yang tinggi. Sehingga hal ini menajadi permasalahan tersendiri di tengah kehidupan sosial di sana.

\section{a. Kurangnya Da i dan Da`iyah}

Melihat wilayah Kanagarian Harau yang cukup luas, maka salah satu yang menjadi permasalahan utama di sana adalah kurangnya jumlah para pendakwah. Sehingga kebutuhan masyarakat terhadap pendakwah untuk pelaksanaan kegiatan kegaamaan agak sulit terpenuhi.

Berdasarkan wawancara kami dengan Bapak Walinagari Harau yaitu Bapak Syukriandi bahwa tidak banyak generasi muda Harau yang melanjutkan pendidikan ke jenjang yang lebih tinggi terutama pendidikan agama. Sehingga hal ini menyebabkan terjadinya krisis ulama, krisis dai, ataupun krisis mubaligh di Kanagarian Harau.

Bahkan untuk melakukan ritual keagaamaan seperti menyelenggarakan jenazah ataupun imam dan khatib shalat jum at harus meminta bantuan ke kempung sebelah. Jika tidak maka aktivitas yang bersifat fardhu kifayah ini tidak bisa dilaksanakan dengan baik.

Semestinya, dalam al-Qur'an telah disebutkan bahwa:

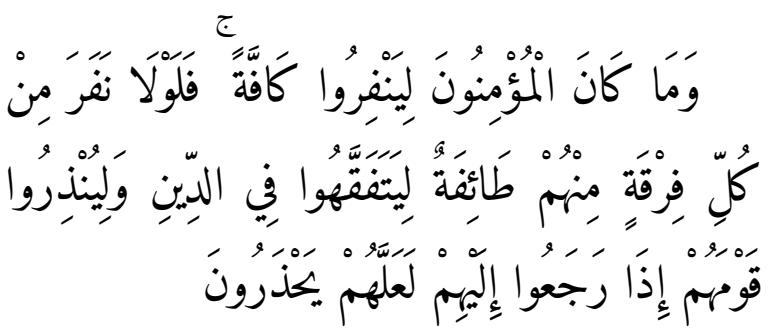

Artinya: Tidak sepatutnya bagi mukminin itu pergi semuanya (ke medan perang). Mengapa tidak, pergi dari tiap-tiap golongan di antara mereka beberapa orang untuk memperdalam pengetahuan mereka tentang agama dan untuk memberi peringatan kepada kaumnya apabila mereka telah kembali kepadanya, supaya mereka itu dapat menjaga dirinya. (QS. At-Taubah: 122)

Dari ayat di atas dipahami bahwa tidak sepantasnya seluruh umat Islam ikut terjun ke medan perang. Artinya memfokuskan pada permasalahan tertentu dan kemudian melalaikan permasalahan yang lain. Maka dalam hal ini, pemahamannya tentu tidak lagi terjun ke medan perang sebab zaman sekarang berbeda konteksnya dengan zaman ketika ayat itu diturunkan. Akan tetapi mungkin saja yang demikian adalah urusan-urasan lainnya yang bersifat keduniaan.

Namun harus dicermati bahwa harus ada sekelompok pemuda dari setiap angkatan atau genareasi untuk ber-tafaqquh atau mendalami ilmu agama. Dan jika mereka telah menyelesaikan pendidikannya, maka kembalilah ke kampung halaman. Sebab kepulangan mereka sangat dinantikan dan kiprah mereka sangat diharapkan sebagai suluh bendang di tengah kampung.

\section{b. Rendahnya Paham Keagamaan}

Memang tidak dinafikan, ada beberapa alim ulama ataupun cadiak pandai yang mereka itu "didabukan salangkan ditinggikan sarantiang" dalam urusan keagamaan di Kanagarian Harau. Akan tetapi permasalahan yang dihadapi disini adalah rendahnya pemahaman da $i$ terhadap permasalaahan keagamaan yang terus berkembang. Sehingga hal-hal yang bersifat khrafat masih lestari ditengah masyarakat seperti tradisi manyaluduak.

Tradisi ini adalah ketika seseorang meninggal dunia, sebelum dikuburkan maka keluarga diminta untuk manyaluduak (berjalan membungkuk) dibawah keranda jenazah. Hal ini bertujuan untuk menghilangkan kesedihan 
bagi anggota keluarga yang ditinggalkan. Dalam Islam tidak ada ritual seperti ini dan hal ini juga telah menyimpang dari tata cara penyelenggaraan jenazah yang diajarkan dalam kitab-kitab fikih.

Tampaknya, praktek seperti ini muncul murni dari pemahaman masyarakat yang mungkin dipengaruhi tradisi-tradisi lama atau hanya hasil ciptaan dari orang-orang tertentu yang kemudian dilaksanakan secara turun termurun di kalangan masyarakat di Kanagarian Harau.

Maka untuk mengatasi hal ini, perlu dilakukan kegiatan yang dapat meningkatkan pemahaman keagamaan pada pendakwah di sana. Agar pemahaman keberagamaan yang lahir adalah pemahaman yang benar bukan pemahaman yang keliru. Dengan demikian terciptalah masyarakat yang dilindungi dan diberkahi oleh Allah Swt.

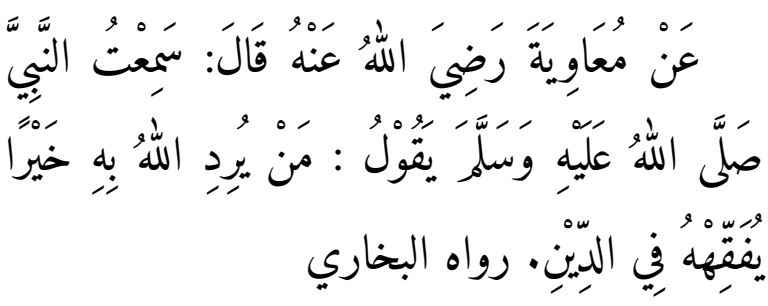

Artinya: "Dari Muawiyyah ra ia berkata, Aku mendengar Nabi saw bersabda: "Siapa yang Alloh kehendaki kebaikan terhadapnya, maka Alloh memahamkannya dalam agama.” (HR. Bukhari)

c. Kurangnya Keterampilan Para Da'I dalam Beberapa Ritual Keagamaan.

Adapun yang dimaksud dengan ritual keagamaan disini adalah penyelenggaraan jenazah dan juga khutbah jum `at. Sebab dua hal ini yang sangat diarasakan kurang oleh masyarakat Kanagarian Harau akan keberadaannya. Sehingga jika ada jenazah, mereka kewalahan untuk mencari sosok yang mampu menyelenggarakan jenazah ini dengan baik. Dan begitu juga dengan khutbah Jum `at, jika khatib tidak datang bisa berakibat gagalnya ibadah jum at pada hari itu karena tidak ada yang bisa menggantikannya.

Berdasarkan penuturan dari masyarakat Hulu Aia Koto Marapak dan Hulu Aia Koto bahwa di tempat mereka sering tidak dilaksakan shalat Jum at. Sebab khatib selalu didatangkan dari luar. Jika hari hujan atau jalan kesana terganggu maka khatib tidak akan datang dan shalat Jum`at tidak dilaksakan.

Seharusnya dalam kondisi seperti ini, harus ada seseorang yang mampu dari wilayah tersebut yang mampu menggantikan khatib sehingga ibadah Jum 'at tetap bisa dilaksanakan. karena tidak ada maka shalat Ibadah Shalat Jum at batal dan akhirnya jamaah hanya melaksakan shalat zuhur.

Dalam kegiatan pengabdian ini, kami melakukan pengkaderan bagi generasi muda Kanagarian Harau untuk memiliki pemahaman yang baik terkait dengan pelaksanaan beberapa ritual keagamaan yang dibutuhkan masyarakat. Sehingga jumlah dai di Kanagarian Harau bertambah dan kebutuhan masyarakat terhadap dai dapat terpenuhi.

Selanjutnya adalah meninggakatkan pemahaman keagamaan para dai yang sudah ada. Hal ini penting untuk dilakukan karena permasalahan yang muncul ditangah masyarakat terus berkembang. Hal ini menuntut para dai harus menguasainya dan kemudian membantu masyarakat dalam menyelesaikannya. Jika tidak maka hal ini akan menjadi konflik ditengah masyarakat sehingga menimbulkan permasalahan baru. Oleh sebab itu dalam hal ini, peningkatan pemahaman dai penting untuk dilakukan agar masyarakat mendapatkan pelita ditengah kegelapan.

Dan yang terakhir yang dilakukan dalam pengabdian ini adalah memberikan pelatihan 
untuk memperbaiki ataupun meningkatkan keterampilan dai di Kanagarian Harau terkait dengan Khutbah Jum at dan Penyelenggaraan jenazah. Sebab dua hal ini sangat dibutuhkan oleh masyarakat disana. Jika khatib dari luar tidak bisa hadir memberikan khutbah, ada dari dai ataupun masyarakat disana yang mampu memberikan khutbah sehingga ibadah jum `at tetap bisa dilaksanakan.

Begitu juga dengan penyelenggaraan jenazah, pelatihan yang diberikan bertujuan untuk membersihkan ritual penyelenggaraan jenazah dari hal-hal yang bersifat khurafat. Menjelaskan kepada masyarakat Kanagarian harau tentang pelaksanaan penyelenggaraan jenazah yang sesuai dengan ajaran Islam. Dengan demikian penyelenggaraan jenazah seseuai dengan tuntunan Rasulullah Saw dan memberikan ketenangan bagi masyakaran di sana.

\section{Penutup}

Sebagai agama yang diturunkan Allah SW'T kepada seluruh para nabi dan rasul. Islam merupakan jalan keselamatan bagi seluruh umat manusia dalam kehidupannya di dunia menuju kehidupan di akhirat nantinya. Dengan diutusnya Nabi Muhammad SAW sebagai penutup dari sekalian nabi dan rasul maka sempurnalah ajaran Islam sehingga tidak ada lagi penambahan ataupun pengurangan dari syariat yang telah disampaikan.

Oleh sebab itu, keluhuran dan kebenaran nilia-nilai ajaran Islam harus disampaikan kepada siapapun dan kapanpun. Aktivitas inilah yang dinamakan dengan dakwah Islamiyah. Dakwah disampaikan tidak hanya terbatas pada kelompok tertentu, golongan tertentu, suku tertentu ataupun bangsa tertentu. Akan tetapi untuk kaffatan linnasi (seluruh umat manusia) kapanpun dan dimanapun.

Dakwah Islam berisikan ajakan kepada yang ma'ruf (kebaikan) dan menjauhi segala hal yang munkar (keburukan). Sebab dengan melaksakan kebaikan dalam kehidupan dan menjauhi segala keburukan maka terciptalah kehidupan yang harmoni dan penuh dengan kebahagiaan.

Dalam setiap aktivitas dakwah, ada enam hal yang harus diperhatikan dengan baik, agar dakwah yang dilakukan tersebut berhasil dan mendatangkan kebaikan. Enam hal tersebut adalah: dai', mad'u, pesan dakwah, media dakwah, feedback dakwah dan metode dakwah. Sedangkan tujuan dari sebuah dakwah adalah untuk memperbaiki kehidupan manusia agar bahagia dunia dan akhirat.

Kenagarian Harau, Kecamatan Harau, Kabupaten Lima Puluh Kota yang merupakan wilayah pengabdian kami, ditemukan beberapa permasalahan yang dihadapi oleh masyarakat terkait dengan aktifitas dakwah. Diantaranya, Pertama, kurangnya jumlah personel da i sehingga tidak terpenuhinya kebutuhan masyarakat terhadap dai. Namun hal ini dapat diatasi dengan menyekolahkan generasi muda Kanagarian Harau untuk ber-tafaqquh atau mendalami ilmu agama di pondok pesantren ataupun di madrasah-madrasah.

Kedua, kurangnya kompetensi dai sehingga hal-hal atau tradisi lama yang tidak sesuai dengan syara menjadi kebiasaan masyarakat. Dalam hal ini perlu mengupgrade atau peningkatan keilmuan para dai dengan melaksanakan kegiatan-kegiatan yang bersifat keagamaan berupa, ceramah agama, tuashiyah ataupun kegiatan-kegiatan keilmuan lainnya.

Sedangakan yang ketiga, kurangnya keterampilan da`i dalam beberapa aktivitas keagamaan terutama pada pelaksanaan ibadah shalat Jum at dan penyelenggaraan jenazah. Maka hal ini dapat di atasi dengan kegiatankegiatan berupa pelatihan-pelatiahan. Baik pelatihan khutbah Jum at atapun pelatihan dalam penyelenggaraan jenazah. Sehingga masyarakat di Kanagarian Harau mampu menyelesaiakan permasalahan-pemasalahan keagamaan yang mereka hadapi dengan baik. 


\section{DAFTAR KEPUSTAKAAN}

Amin, Samsul Munir. 2009. Ilmu Dakwah. Jakarta: Amzah.

Aziz, Moh. Ali. 2004. Ilmu Dakwah. Jakarta: Pranadamedia Group.

Ghazali. 1997. Dakwah Komunikatif: Membangun Kerangka Dasar Ilmu Komunikasi Dakwah. Jakarta: Pedoman Ilmu.

Habib, M. Syafaat. 1982. Buku Pedoman Dakwah. Jakarta: Widjaya.

Ilahi, Wahyu 2013. Komunikasi Dakwah. Bandung: PT Remaja Rosdakarya.

Kafie, Jamaluddin. 1993. Psikologi Dakwah: Bidang Studi dan Bahan Acuan. Surabaya: Offset Indah.

Mahfud, Sahal. 1994. Nuansa Fiqih Sosial. Yogyakarta: LkiS.

Mahfudz, Ali. 1952. HidayatAl-Mursyidin. Cairo; Dar Al-Kutub Al-Arabiyah.

Munir, M. 2003. Metode Dakwah. Jakarta: Prenadamedia Group.

Muriah, Siti. 2000. Metodologi Dakwah Kontemporer. Yogyakarta: Mitra Pustaka.

Nasir, Mohammad. 2000. Fiqhud Da'wah. Jakarta: Media Dakwah.

Omar, Toha Yahya. 2004. Islam dan Dakwah. Jakarta: Zakia Islami Press.

Raharjo, M. Dawam. 2002. Islam dan Transformasi Budaya. Yogyakarta: Dana Bhakti Prima Yasa. 